\title{
Effects of Dietary Brewery Spent Grain Inclusion on Egg Laying Performance and Quality Parameters of Bovans Brown Chickens
}

\section{mAuthor(s)}

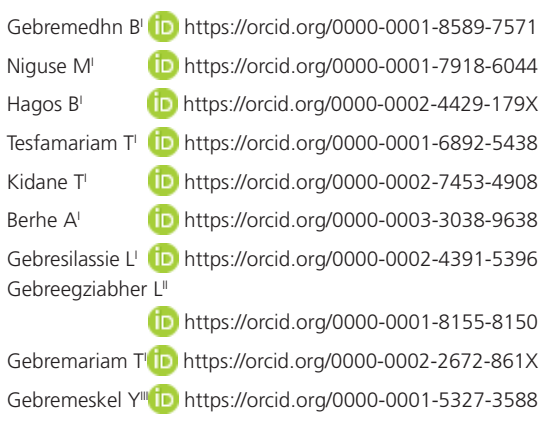

Department of Animal, Rangeland and Wildlife Sciences, Mekelle University, P.O.Box: 231, Tigray, Ethiopia.

" Department of Animal Science, Wukro Agricultural Polytechnic college, Tigray, Ethiopia.

III Tigray Region Women Affairs Office Head.

\section{-Mail Address}

Corresponding author e-mail address Gebremedhn Beyene

Department of Animal, Rangeland and Wildlife Sciences, Mekelle University,

P.O.Box: 231, Tigray, Ethiopia

Phone: 251-966280075

Email: gebremedhnb2008@gmail.com

\section{nKeywords}

Bovans brown, brewery spent grain, egg quality, productivity, profitability.

\section{ABSTRACT}

Poultry rations are composed mainly of conventional cereal grains and proteins. Using non-conventional agro-industrial by-products may reduce the cost of production and thereby improve productivity. A study was conducted to evaluate the effect of dietary brewery spent grain inclusion on egg laying performance, quality parameters of bovans brown and profitability of the rations. A total of 200 pullets with similar body weight and age were randomly distributed to five treatments with four replications. The treatments were brewery spent grain (BSG) inclusion of $0,10,20,30$ and $40 \%$ levels for T1, T2, T3, T4 and T5, respectively. The $\mathrm{CP}$ and $\mathrm{ME}$ contents of treatment rations were 16.54$17.04 \%$ and $2871-2903 \mathrm{kcal} / \mathrm{kg} \mathrm{DM}$, respectively. Inclusion of the BSG in the layers ration did not affect dry matter intake, feed conversion efficiency and hen-day egg production (58.79, 57, 56.11, 55.11 and $54.13 \%(S E M=0.92))$. Likewise, the inclusion of the BSG in the diets did not affect (albumen, yolk, shell) quality. However, feed cost decreased with the increasing level of the BSG in the rations because of its lower purchasing price. To conclude, a $40 \%$ inclusion of BSG in the diet of layers does not affect the production and the quality of the eggs and it can be economically profitable.

\section{INTRODUCTION}

In Ethiopia, poultry production is popular in urban (66\%) and rural $(53 \%)$ areas (Birol et al., 2010). The total chicken population in the country is estimated to be 59.5 million, being 90.85 percent of the indigenous breed, 4.76 percent of the hybrid breed and 4.39 percent of the exotic breed (CSA, 2017). However; the economic contribution of the sector is still not proportional to the huge numbers of chicken; for instance the estimate of egg and poultry meat production is about 40,000 and 60,480 ton respectively (Faostat, 2013). This is due to the presence of many technical, organizational and institutional constraints (Fisseha et al., 2010). The availability in terms of quantity and quality and cost of feed is one of the major limitations to livestock production systems in Sub-Saharan Africa (Alemayehu \& Yayneshet, 2011). In Ethiopia scarcity of poultry feed is the major problem and the expected economic returns from chicken are very low. The price of feed sources is the determining factors for the profit margins in poultry production. Therefore, utilization of alternative feed resources in poultry ration is a best option for successful poultry production (Zewdu \& Berhan, 2014). These alternative feed ingredients can be the non-conventional feed sources like brewery spent grains. Brewers spent grain is the byproduct remaining after fermentation of the grain, during the beer making process. The by-product varies nutritionally from plant to plant and depending upon the type of substrate (barley, wheat, corn, etc.), extent of fermentation and type of fermentative process (Levic et al., 
Gebremedhn B, Niguse M, Hagos B, Tesfamariam T, Kidane T, Berhe A, Gebresilassie L, Gebreegziabher L, Gebremariam T, Gebremeskel Y
Effects of Dietary Brewery Spent Grain Inclusion on Egg Laying Performance and Quality Parameters of Bovans Brown Chickens
2010). It is available at low or no cost throughout the year, and it is produced in large quantities (Mussatto et al., 2006). The availability of brewery plants creates great opportunity for utilizing these agro-industrial byproducts in poultry as protein sources (Meseret et al., 2012). They are rich sources of digestible fiber with good amino acids, B- vitamin and phosphorus but low in other minerals (Hosseini et al., 2010). Every year a large amount of brewery by-product is produced in Ethiopia. However, the by-product has not yet been extensively utilized for egg type poultry. Small amounts of the product is utilized as dairy cattle feed and large volume is accumulated at the production sites which causes disposal and public health problems (Zewdu \& Berhan, 2014). The residue from production of 100 liters of beer is about $20 \mathrm{~kg}$ fresh matter residue with 80 $\%$ moisture content (Briggs et al., 2004). Considering Ethiopia's nationwide beer production capacity of about 5.8 million hectoliters, 1.16 million metric tons of brewery spent grain (BSG) can be produced. Particularly, Raya beer has the capacity to produce 0.71 million hectoliters of beer and 14.2 million $\mathrm{kg}$ of BSG (Ethiopian-Reporter, 2015). Therefore; effective utilization and development of dietary formulations which allow locally available new ingredients such as brewery by-products is the most appropriate strategy as an alternative animal feed (Zewdu \& Berhan, 2014). Hence, this study was designed to evaluate the effect of dried brewery grain inclusion in poultry diet on laying performance, egg quality using Bovans Brown layers and evaluate the profitability of the inclusion of brewery dried grain in layers diet.

\section{MATERIALS AND METHODS}

\section{The study site}

The experiment was conducted at Mekelle University poultry farm, $783 \mathrm{~km}$ north of Addis Ababa, Ethiopia. The site is located at $13^{\circ} 28^{\prime} \mathrm{N}$ latitude and $39^{\circ} 29^{\prime} \mathrm{E}$ longitude with an altitude ranging of 2150 2250 meter above sea level. The mean annual rainfall and temperature of the area is $680 \mathrm{~mm}$ and $17{ }^{\circ} \mathrm{C}$, respectively (Alemayehu \& Yayneshet, 2011).

\section{Experimental rations and treatments}

Five experimental diets were formulated using feedwin software and the brewery dried grain was included at a rate of $0 \%, 10 \%, 20 \%, 30 \%$ and $40 \%$ level for T1 (control), T2, T3, T4 and T5, respectively. The feed ingredients used in the formulation of the different experimental rations were brewers spent grain (BSG), maize grain (MG), wheat short, noug seed cake (NSC), soybean meal (SBM), vitamin premix, salt and limestone. The brewery spent grain (BSG) was purchased from Raya Beer share company and the rest feed ingredients were purchased from nearby local market. The wet brewery grain was open air dried by spreading on Polyethylene plastic sheet for 4 consecutive days. To ensure uniform drying the brewers spent grain was turned and mixed up $5-6$ times a day to break large particles. BSG was kept in air tight bags after drying. BSG, MG, NSC, and SBM were hummer milled to $5 \mathrm{~mm}$ sieve size and stored until required for formulation of the experimental rations. The chemical composition of the feed ingredients used for formulation of dietary ration was determined before formulation of the dietary treatments. The five dietary treatments were formulated to be iso-caloric and iso-nitrogenous with 2800-2900 kcal ME/kg DM and $16-17 \%$ CP (NRC, 1994) to meet the nutrient requirements of the layers. The proportion of the experimental diets was determined after nutrient analysis based on the nutrient content of the ingredients (Table 1).

Table 1 - Proportion of ingredients (\%) and analyzed chemical composition of the treatment ration

\begin{tabular}{lccccc}
\hline Ingredients & \multicolumn{5}{c}{ Treatment diets } \\
\cline { 2 - 6 } & T1 & T2 & T3 & T4 & T5 \\
\hline BSG & 0.00 & 10.00 & 20.00 & 30.00 & 40.00 \\
Wheat short & 25.00 & 21.00 & 17.00 & 14.00 & 10.70 \\
Soybean meal & 7.00 & 5.00 & 2.00 & 2.00 & 0.00 \\
Maize & 34.50 & 34.20 & 36.20 & 36.20 & 39.00 \\
Noug seed cake & 24.20 & 20.50 & 15.50 & 8.50 & 1.00 \\
Limestone & 8.00 & 8.00 & 8.00 & 8.00 & 8.00 \\
Salt & 0.50 & 0.50 & 0.50 & 0.50 & 0.50 \\
Vitamin premix & 0.80 & 0.80 & 0.80 & 0.80 & 0.80 \\
Total & 100 & 100 & 100 & 100 & 100 \\
\hline
\end{tabular}

$\mathrm{BSG}=$ Brewery spent grain; $\mathrm{T} 1=$ ration containing $0 \% \mathrm{BSG} ; \mathrm{T} 2=$ ration containing 10\% BSG; T3 = ration containing 20\% BSG; $\mathrm{T} 4$ = ration containing 30\% BSG; T5= ration containing 40\% BSG

\section{Experimental design and management of Bovans Brown layers}

The layers were kept in deep litter pens covered with $10 \mathrm{~cm}$ deep barely straw as litter material. Before the commencement of the actual experiment, the pens, feeders, drinkers and laying nests were thoroughly cleaned, disinfected and sprayed against external parasites. A total of 200 Bovans brown of 20 weekold layers with similar body weight were used in a completely randomized design (CRD). The layers were randomly allocated into 5 treatments. Each treatment comprised 40 layers and each treatment group was further subdivided into 4 replicates which comprised 10 
Gebremedhn B, Niguse M, Hagos B, Tesfamariam T, Kidane T, Berhe A, Gebresilassie L, Gebreegziabher L, Gebremariam T, Gebremeskel Y
Effects of Dietary Brewery Spent Grain Inclusion on Egg Laying Performance and Quality Parameters of Bovans Brown Chickens layers in each. The layers were adapted to experimental diets for 7 days before the commencement of data collection. Feed was offered twice a day at 08:00 and 16:00 hours and clean tap water was available at all times. The experiment lasted 12 weeks.

\section{Data collection and measurements}

\section{Chemical analysis}

Representative feed samples were taken and subjected to proximate method of AOAC (1990) to determine dry matter (DM), crude protein (CP), crude fiber (CF), Ether extract (EE) and total ash content. The nitrogen was determined by using the Kjeldhal procedure and CP was computed by multiplying the nitrogen $(N)$ content by 6.25 . The metabolizable energy (ME) value was determined indirectly following the method given by Wiseman (1987) as follows: ME $(\mathrm{Kcal} / \mathrm{kg} \mathrm{DM})=3951+54.4 \mathrm{EE}-88.7 \mathrm{CF}-40.8$ Ash. The calcium and phosphorus content were determined by atomic absorption spectrophotometer. Chemical analyses were carried out in duplicate.

\section{Feed intake and feed conversion efficiency}

Weighed amount of feed was provided to the experimental birds twice a day at 08:00 and 16:00. Feed offered and refused per pen was recorded daily. The amount of feed consumed was determined as the difference of the feed offered and the feed refused. Feed offered and refused were sampled daily per pen and pooled per treatment for the entire experimental period for chemical analysis. Hens were weighted at the start and end of the experiment and body weight change was calculated as the difference between the final and initial body weight.

Feed conversion efficiency was determined per replicate by dividing daily grams of eggs laid by daily grams of feed intake in DM.

$$
\text { i.e. } \mathrm{FCE} \%=\frac{\mathrm{DLE}(\mathrm{g})}{\mathrm{DFI}(\mathrm{g})} * 100
$$

\section{Egg production}

Eggs were collected 3 times a day at 08:00, 13:00 and 17:00 hrs from each pen. The sum of the collections along with the number of birds alive on each day were recorded and summarized at end of the period. Eggs collected daily were weighted for each pen and average egg weight was computed by dividing the total egg weight to the number of eggs collected. Hen-day and hen- housed egg production were calculated following the method given by Hunton (1995).

$$
\% \text { Hen-day egg production }=\frac{\begin{array}{c}
\text { Number of eggs } \\
\text { collected per day }
\end{array}}{\begin{array}{c}
\text { Number of hens } \\
\text { present on that day } \\
\text { Number of eggs }
\end{array}} \times 100
$$

\section{Egg quality measurements}

A total of 9 eggs per treatment (i.e. 3 eggs per replicate) were randomly taken weekly starting from the $5^{\text {th }}$ week to the $12^{\text {th }}$ week of the experimental period for egg quality analysis. Then the average was computed for each quality parameters for the replicate. Egg quality parameters, such as egg weight, shell weight, shell thickness, yolk weight, albumin weight, yolk height, albumin height, yolk index, yolk color and Haugh unit were measured. Egg shell thickness was measured using electronic digital caliper. Egg shell weight, albumen weight and yolk weight were measured by sensitive balance. Haugh unit measurement technique was used to relate the weight of the eggs with the height of thick albumen. Haugh unit was calculated according to the method described by Haugh (1937) formula as:

$$
\text { Haugh unit }(\mathrm{HU})=100 \log \left(\mathrm{AH}+7.6-1.7 \mathrm{EW}^{0.37}\right)
$$

Where: $\mathrm{AH}=$ Albumen height and

$$
\mathrm{EW}=\text { Egg weight }
$$

Yolk diameter and height were measured using ruler and electronic digital caliper, respectively after separation of the yolk from the albumen. The weight of the yolk was measured using sensitive balance of $0.005-3 \mathrm{~kg}$ capacity. Yolk index was estimated in percentage, taking the ratio of their respective heights to the average diameter (breadth and length) using the following formula.

$$
\text { yolk index } \%=\frac{\text { Yolk height }(\mathrm{cm})}{\text { Yolk diameter }(\mathrm{cm})} \times 100
$$

Yolk color measurement was made after the removal of the the yolk's membrane, the whole yolk was thoroughly mixed, and a yolk sample was taken on a piece of white paper and compared with Roche fan measurement strips.

\section{Partial budget analysis}

To estimate and compare the economic feasibility of including brewery spent grains in layers diet, partial budget analysis was employed according to Upton 
Gebremedhn B, Niguse M, Hagos B, Tesfamariam T, Kidane T, Berhe A, Gebresilassie L, Gebreegziabher L, Gebremariam T, Gebremeskel Y
Effects of Dietary Brewery Spent Grain Inclusion on Egg Laying Performance and Quality Parameters of Bovans Brown Chickens
(1979). The partial budget was calculated as the difference between the feed costs incurred during the experimental periods and sale of the eggs. The net return (NR) was calculated by subtracting total variable cost (TVC) from total return (TR). The change in net return $(\triangle N R)$ was computed by subtracting change in variable cost $(\triangle T V C)$ from change in total return $(\triangle T R)$. The marginal rate of return (MRR) quantifies the increase in net return associated with each additional unit of expenditure. This is expressed by percentage as:

$$
M R R \%=\frac{\Delta N R}{\Delta T V C} \times 100
$$

The variable costs were the same for all treatments except the feed cost. The feed costs were calculated based on the market price of each ingredient and percent of inclusion. While the cost of brewery spent grain included the factory price, transport and processing costs. Market price of the eggs during the experimental period was considered as total return.

\section{Statistical analysis}

The collected data were subjected to analysis of variance (ANOVA). Except yolk color, which was analyzed by logistic regression, all other parameters were statistically analyzed using general linear model procedure of SAS (SAS, 2008). Significant difference $(p \leq 0.05)$ between treatments means were separated using Tukey's Studentized Range Test (HSD) method. The model used for statistical analysis was:

$$
\begin{aligned}
& \text { Yij }=\mu+\mathrm{Ti}+\text { eij } \\
& \text { Where: } Y_{i j}=\text { responsible variable } \\
& \mu=\text { over all means } \\
& \mathrm{Ti}=\mathrm{i}^{\text {th }} \text { treatment effect }(\mathrm{i}=1,2,3,4,5) \\
& \mathrm{eij}=\text { is a random error }
\end{aligned}
$$

\section{RESULTS}

\section{Chemical and nutritional composition of BSG and the treatment diets}

The result, as illustrated in (table 2), showed BSG has a lower CP content by $5.39 \%$ but a higher ME level

\begin{tabular}{|c|c|c|c|c|c|}
\hline \multirow{2}{*}{$\begin{array}{l}\text { Chemical } \\
\text { Composition }\end{array}$} & \multicolumn{5}{|c|}{ Feed ingredients } \\
\hline & BSG & NSC & MG & WS & SBM \\
\hline DM (\%) & 92.80 & 92.10 & 90.20 & 90.30 & 93.10 \\
\hline $\mathrm{CP}(\% \mathrm{DM})$ & 28.10 & 29.70 & 8.53 & 15.70 & 37.80 \\
\hline $\mathrm{EE}(\% \mathrm{DM})$ & 4.35 & 9.21 & 5.20 & 3.20 & 7.30 \\
\hline Ash (\% DM) & 4.25 & 8.30 & 5.92 & 6.10 & 7.93 \\
\hline CF (\% DM) & 14.30 & 16.10 & 4.10 & 8.90 & 6.30 \\
\hline $\mathrm{Ca}(\% \mathrm{DM})$ & 0.25 & 0.51 & 0.03 & 0.06 & 0.33 \\
\hline $\mathrm{P}(\% \mathrm{DM})$ & 0.94 & 0.33 & 0.27 & 0.35 & 0.85 \\
\hline ME (Kcal/kg) & 2745.83 & 2685.31 & 3628.67 & 3086.77 & 3465.77 \\
\hline
\end{tabular}
by $2.25 \%$ compared to NSC. BSG has the lowest ash but the highest $P$ content among the feed ingredients. Besides, BSG has higher CF level than all the other feed ingredients except NSC.

Table 2 - Chemical composition of ingredients used in formulation of dietary treatment rations.

$\mathrm{DM}=$ dry matter; $\mathrm{CP}=$ crude protein; $\mathrm{EE}=$ ether extract; $\mathrm{CF}=$ crude fiber; $\mathrm{Ca}=$ calcium; $\mathrm{P}=$ phosphorus; $\mathrm{ME}=$ metabolizable energy; $\mathrm{BSG}=$ brewery spent grain; NSC=noug seed cake; $M G=$ maize grain; $W S=$ wheat short; $S B M=$ soybean meal.

Similar levels of CP and ME were revealed by the results among all the treatments in the range of

\begin{tabular}{|c|c|c|c|c|c|}
\hline \multirow{2}{*}{$\begin{array}{l}\text { Chemical } \\
\text { composition }\end{array}$} & \multicolumn{5}{|c|}{ Treatments } \\
\hline & $\mathrm{T} 1$ & $\mathrm{~T} 2$ & T3 & $\mathrm{T} 4$ & T5 \\
\hline $\mathrm{DM}(\%)$ & 91.83 & 91.93 & 92.00 & 92.09 & 92.18 \\
\hline $\mathrm{CP}(\% \mathrm{DM})$ & 17.04 & 17.00 & 16.74 & 16.72 & 16.54 \\
\hline Ash (\% DM) & 6.17 & 5.83 & 4.48 & 5.12 & 4.75 \\
\hline $\mathrm{EE}(\% \mathrm{DM})$ & 5.39 & 5.14 & 4.87 & 4.51 & 4.20 \\
\hline CF (\% DM) & 8.17 & 8.32 & 8.48 & 8.43 & 8.43 \\
\hline $\mathrm{P}(\% \mathrm{DM})$ & 0.32 & 0.37 & 0.41 & 0.47 & 0.52 \\
\hline $\mathrm{Ca}(\% \mathrm{DM})$ & 3.38 & 3.37 & 3.36 & 3.34 & 3.32 \\
\hline ME (kcal/kg DM) & 2903 & 2889 & 2874 & 2873 & 2871 \\
\hline
\end{tabular}
$16.54-17.04 \%$ and $2871-2903 \mathrm{kcal} / \mathrm{kg}$ respectively.
However, a slight continuous decrease in both can be noticed as the level of BSG increases across the treatments (table 3).

Table 3 - Chemical composition of treatment diets containing different proportions of brewery spent grain

$\mathrm{DM}=$ dry matter; $\mathrm{CP}=$ crude protein; $\mathrm{EE}=$ ether extract; $\mathrm{CF}=$ crude fiber; $\mathrm{P}=$ phosphorous; $\mathrm{Ca}=$ calcium; $\mathrm{ME}=$ metabolizable energy; $\mathrm{BSG}=$ brewery spent grain; $\mathrm{T} 1=$ ration containing 0\% BSG; T2 = ration containing 10\% BSG; T3 = ration containing 20\% BSG; T4 = ration containing 30\% BSG; T5= ration containing 40\% BSG 
Gebremedhn B, Niguse M, Hagos B, Tesfamariam T, Kidane T, Berhe A, Gebresilassie L, Gebreegziabher L, Gebremariam T, Gebremeskel Y

\section{Effects of Dietary Brewery Spent Grain Inclusion on Egg Laying Performance and Quality Parameters of Bovans Brown Chickens}

\section{Feed intake and body weight change}

The differences in feed intake due to the treatments were non-significant $(p>0.05)$. However, there was a tendency of increase in feed intake as the level of BSG increases. The highest feed intake was recorded for T5. Similarly, no significant difference was found in body weight change and due to the treatments while a slight continuous increase in body weight change was noticed from T1 to T5 (table 4).

\section{Egg production performance, egg weight, egg mass and feed conversion efficiency}

As indicated in (table 4), both hen day egg production (HDEP) and hen housed egg production
(HHEP) showed no significant difference due to the treatments $(p>0.05)$. HDEP and HHEP value in all of the respective treatments were equal because of zero mortality during the 90 days experimental period. A continuous slight decline in values of HDEP and HHEP were noticed as the BSG level increased along $T 1, T 2, T 3$, T4 and T5. Similarly, egg weight and egg mass showed no significant difference due to the treatments. The highest egg weight (52.09g) and egg mass (30.63g/ hen/day) was T1 while the lowest values for T5 showed a percentage reduction of 2.03 and 9.86 respectively. Consequently, feed conversion efficiency continuously reduced along the treatments from T1 to T5 though the differences were non-significant.

Table 4 - Dry matter intake, body weight gain and egg laying performance of Bovans Brown hens fed ration containing different levels of brewery spent grain

\begin{tabular}{|c|c|c|c|c|c|c|c|}
\hline \multirow{2}{*}{$\begin{array}{l}\text { Treatment } \\
\text { Parameters }\end{array}$} & \multirow[b]{2}{*}{ T1 } & \multirow[b]{2}{*}{$\mathrm{T} 2$} & \multirow[b]{2}{*}{ T3 } & \multirow[b]{2}{*}{ T4 } & \multirow[b]{2}{*}{ T5 } & \multirow[b]{2}{*}{ SEM } & \multirow[b]{2}{*}{$p$-value } \\
\hline & & & & & & & \\
\hline DMI (g/bird/day) & 88.91 & 89.04 & 89.26 & 89.92 & 90.19 & 0.42 & 0.1866 \\
\hline Initial BW (g/bird) & 1410 & 1415 & 1420 & 1412.67 & 1408.33 & 2.05 & 0.9192 \\
\hline Final BW (g/bird) & 1506.3 & 1514 & 1522 & 1531.3 & 1540.7 & 2.13 & 0.2309 \\
\hline BW gain (g/bird) & 96.3 & 99 & 102 & 118.7 & 132.3 & 2.54 & 0.4210 \\
\hline AD gain (g/bird) & 1.07 & 1.1 & 1.13 & 1.32 & 1.47 & 0.27 & 0.4210 \\
\hline Total egg/hen & 52.91 & 51.30 & 50.50 & 49.60 & 48.70 & 0.87 & 0.5309 \\
\hline $\operatorname{HDEP}(\%)$ & 58.79 & 57 & 56.11 & 55.11 & 54.10 & 0.92 & 0.5309 \\
\hline $\operatorname{HHEP}(\%)$ & 58.79 & 57 & 56.11 & 55.11 & 54.10 & 0.92 & 0.5309 \\
\hline Egg weight (g) & 52.09 & 51.87 & 51.7 & 51.26 & 51.03 & 0.37 & 0.1918 \\
\hline EM (g/hen/day) & 30.63 & 29.56 & 29.01 & 28.25 & 27.61 & 0.66 & 0.3129 \\
\hline FCE (g egg /g feed) & 34.45 & 33.20 & 32.50 & 31.42 & 30.61 & 0.072 & 0.2487 \\
\hline
\end{tabular}

$\mathrm{AD}=$ average daily; $\mathrm{DMI}=$ dry matter intake; $\mathrm{BW}=$ body weight; $\mathrm{FCE}=$ feed conversion Efficiency; $\mathrm{HDEP}=$ hen-day egg production; HHEP = hen-housed egg production; $\mathrm{EM}=$ egg mass; $\mathrm{SEM}=$ standard error of mean; $\mathrm{BSG}=$ brewery spent grain; $\mathrm{T} 1=$ ration containing $0 \% \mathrm{BSG} ; \mathrm{T} 2=$ ration containing $10 \%$ BSG as an inclusion; $\mathrm{T3}=$ ration containing $20 \% \mathrm{BSG}$ as an inclusion; $\mathrm{T} 4=$ ration containing $30 \% \mathrm{BSG}$ as an inclusion; $\mathrm{T} 5=$ ration containing $40 \% \mathrm{BSG}$ as an inclusion.

\section{Egg quality}

As indicated in (table 5), none of the egg quality parameters showed significant differences due to the treatments. Shell weight tended to reduce as the level of BSG increased. The highest shell weight was obtained in T1 (5.90) while the lowest (T5) showed a $5.42 \%$ reduction. The highest haugh unit is 92.96 for T4 and the treatments did not have any significant

Table 5 - Egg quality parameters of Bovans Brown hens fed ration containing different levels of brewery spent grain

\begin{tabular}{|c|c|c|c|c|c|c|c|}
\hline \multirow[t]{2}{*}{ Parameters } & \multicolumn{7}{|c|}{ Treatments } \\
\hline & T1 & $\mathrm{T} 2$ & T3 & T4 & T5 & SEM & $p$-value \\
\hline Sample Egg weight (g) & 52.34 & 51.42 & 50.94 & 50.32 & 50 & 0.67 & 0.5506 \\
\hline Shell weight (g) & 5.9 & 5.83 & 5.74 & 5.66 & 5.58 & 0.18 & 0.0902 \\
\hline Shell thickness (mm) & 0.34 & 0.33 & 0.33 & 0.33 & 0.32 & 0.062 & 0.7060 \\
\hline Albumen height (mm) & 7.95 & 8.04 & 8.09 & 8.15 & 8.1 & 0.36 & 0.9912 \\
\hline Albumen weight (g) & 30.75 & 30.07 & 29.79 & 29.33 & 29.15 & 0.65 & 0.8039 \\
\hline Yolk height (mm) & 15.35 & 15.42 & 15.52 & 15.61 & 15.7 & 0.28 & 0.6822 \\
\hline Yolk weight (g) & 15.69 & 15.52 & 15.41 & 15.33 & 15.27 & 0.39 & 0.9171 \\
\hline Yolk color score & 3.74 & 4.10 & 4.14 & 4.36 & 4.36 & 0.35 & 0.5276 \\
\hline Yolk diameter $(\mathrm{cm})$ & 3.65 & 3.61 & 3.58 & 3.53 & 3.5 & 0.15 & 0.3401 \\
\hline Yolk index & 0.42 & 0.43 & 0.43 & 0.44 & 0.45 & 0.057 & 0.1703 \\
\hline Haugh unit & 91.37 & 92.10 & 92.49 & 92.96 & 92.79 & 0.86 & 0.9654 \\
\hline
\end{tabular}

SEM = standard error of mean; BSG= brewery spent grain; $\mathrm{T} 1=$ ration containing $0 \%$ BSG as an inclusion; $\mathrm{T} 2$ = ration containing $10 \%$ BSG as an inclusion; $\mathrm{T} 3=$ ration containing $20 \%$ BSG as an inclusion; $\mathrm{T4}$ = ration containing 30\% BSG as an inclusion; $\mathrm{T} 5=$ ration containing $40 \% \mathrm{BSG}$ as an inclusion 
Gebremedhn B, Niguse M, Hagos B, Tesfamariam T, Kidane T, Berhe A Gebresilassie L, Gebreegziabher L, Gebremariam T, Gebremeskel Y
Effects of Dietary Brewery Spent Grain Inclusion on Egg Laying Performance and Quality Parameters of Bovans Brown Chickens effect. Similarly, yolk weight showed no significant difference due to the treatments but only a tendency to reduce as the level of BSG increased from T1 to T5.

\section{Partial economic analysis}

The profitability analysis, as indicated in (table 6), showed the highest $M R R=22.86$ for T5. The MRR continuously increased as the level of BSG increased from $10 \%$ in T2 to $40 \%$ in T5. Feed cost/dozen egg was the lowest in $\mathrm{T} 5$ showing a $21.35 \%$ reduction from the highest in T1. The decrease in feed cost between the control diet (6.60 birr per $\mathrm{kg}$ feed) and the diet with $40 \%$ inclusion level (4.50 birr per $\mathrm{kg}$ feed) represents a $31.19 \%$ reduction in the cost of feed which will be of great benefit to beneficiaries. The increase in egg sale/ feed cost was continuous as BSG level increased along T1 to T5. The highest egg sale/feed cost 3.41 of T5 is by 27.24 percent higher than the lowest 2.68 of $\mathrm{T} 1$.

Table 6 - Economics of inclusion of brewery spent grain in the layers ration

\begin{tabular}{|c|c|c|c|c|c|}
\hline \multirow[t]{2}{*}{ Variable } & \multicolumn{5}{|c|}{ Treatments } \\
\hline & $\mathrm{T} 1$ & $\mathrm{~T} 2$ & T3 & T4 & T5 \\
\hline Total feed consumed $(\mathrm{kg})$ & 271.25 & 274.78 & 277.85 & 281.65 & 285.47 \\
\hline Total feed cost/ treatment (birr) & 1776.83 & 1590.17 & 1413.73 & 1262.67 & 1086.79 \\
\hline Labor cost (for processing BDG) (birr) & 0 & 50 & 100 & 150 & 200 \\
\hline TVC (birr) & 1776.83 & 1640.17 & 1513.73 & 1412.67 & 1286.79 \\
\hline Feed cost/kg (Birr) & 6.6 & 6.0 & 5.4 & 5.0 & 4.5 \\
\hline Total egg produced & 1587 & 1539 & 1515 & 1488 & 1461 \\
\hline Gross income (TR)(birr) & 4761 & 4617 & 4545 & 4464 & 4383 \\
\hline Net income ( NI) (birr) & 2984.17 & 2976.83 & 3031.27 & 3051.33 & 3096.21 \\
\hline$\triangle T R$ (birr) & - & -144 & -216 & -297 & -378 \\
\hline$\triangle T V C$ (birr) & - & -136.66 & -263.1 & -364.16 & -490.04 \\
\hline$\triangle N R$ (birr) & - & -7.34 & 47.1 & 67.16 & 112.04 \\
\hline MRR (\%) & - & 5.37 & 17.90 & 18.44 & 22.86 \\
\hline Dozens of egg & 132.25 & 128.25 & 126.25 & 124 & 121.75 \\
\hline Feed cost/dozen egg (birr) & 13.44 & 12.79 & 11.99 & 11.39 & 10.57 \\
\hline Egg sale/Feed cost (birr) & 2.68 & 2.81 & 3.00 & 3.16 & 3.41 \\
\hline
\end{tabular}

Birr is Ethiopian currency; egg sale=3birr/egg; trt= treatment; $\mathrm{BSG}=$ brewery dried grain; $\mathrm{T} 1=$ ration containing $0 \%$ BSG as an inclusion; $\mathrm{T} 2=$ ration containing $10 \%$ BSG as an inclusion; T3 = ration containing 20\% BSG as an inclusion; T4 = ration containing 30\% BSG as an inclusion; T5= ration containing $40 \%$ BSG as an inclusion.

\section{DISCUSSION}

\section{Chemical and nutritional composition of BSG and the treatment diets}

The BSG used in this study has a $D M=92.80 \%$, $\mathrm{CP}=28.10 \%, \mathrm{EE}=4.35 \%, \quad \mathrm{CF}=14.30 \% \quad \mathrm{Ash}=4.25 \%$ and $\mathrm{ME}=2745.83 \mathrm{kcal} / \mathrm{kg}$. In comparison, (NRC, 1994; Demeke, 2007; Fărcas et al., 2014; Zewdu \& Berhan, 2014; John, 2015) reported a DM content of $92.00 \%, 91.80 \%, 94.30 \%, 91.01 \%, 93.17 \%$ for BSG respectively. The CP content of BSG revealed in this study is higher than what is reported by (Fărcas et al., 2014) (18\%), (John, 2015) (23.67\%), (Demeke, 2007) (24\%), (Swain et al., 2013) (25\%), (Heuze et al., 2015) (25.8\%), (Briggs et al., 2004) (27\%) and (Mafeni \& Fombad, 2001) (27.7\%) when placed in ascending order and in between the range (28-30\% ) reported in (Mussatto et al., 2006). The EE of BSG as revealed by the current result is $4.35 \%$ which is low compared to (Swain et al., 2013) (5.06\%), (Demeke, 2007) (6.30\%), (Mafeni \& Fombad, 2001) (7.20\%), and (John, 2015) (8.91\%) but higher than $3.06 \%$ reported in (Zewdu \& Berhan, 2014). Mafeni \& Fombad (2001) and John
(2015) reported ash content of BSG 3.80\% and 3.86\% respectively while the current study found a higher ash level of $(4.25 \%)$ in close to agreement with (Briggs et al., 2004) 4-5\%, and (Zewdu \& Berhan, 2014) (4.79 $\%)$. In contrast, Swain et al. (2013) reported an ash content of $7.50 \%$ for BSG. The CF level of BSG in this study $(14.30 \%)$ is comparable to the values in (NRC, 1994) (15\%), (Briggs et al., 2004) $(15.30 \%)$, and (Mafeni \& Fombad, 2001) (15.70\%) but by far lower than in (John, 2015) (39.2\%). The closeness of CF level of BSG and NSC (16.10\%) in this study seems to have helped the comfortable replacement of much of the NSC with BSG up to the $40 \%$ inclusion level without significant effect on egg production performance and egg quality. In reflection to the above discussed chemical composition variables, the ME content of BSG according to this study is $2745.83 \mathrm{kcal} / \mathrm{kg}$ which is higher than what was reported in (Demeke, 2007) (2510 kcal/ $/ \mathrm{kg}$ ) and (Heuze et al., 2015) (2200 kcal/ $\mathrm{kg})$. The variation in nutrient content of BSG among different sources is attributed to the type of raw material (barley, maize, wheat,...), type of fermentative process and extent of fermentation (Levic et al., 2010), barley 
Gebremedhn B, Niguse M, Hagos B, Tesfamariam T, Kidane T, Berhe A, Gebresilassie L, Gebreegziabher L, Gebremariam T, Gebremeskel Y
Effects of Dietary Brewery Spent Grain Inclusion on Egg Laying Performance and Quality Parameters of Bovans Brown Chickens variety, time of harvest, characteristics of hops and other adjuncts added and brewery technology (Santos et al., 2003). All the diets are in agreement with the recommendations of (NRC, 1994) $16-17 \%$ for CP and $2800-2900 \mathrm{kcal} / \mathrm{kg}$ for ME. The Ca contents of all the diets are comparable to (Leeson \& Summers, 1997) and (Jacob et al., 2000).

\section{Feed intake and body weight change}

As indicated in the results, there was no significant difference in DM intake between the treatments. The positive correlation stated in (Demeke, 2007) between feed intake and digestibility could suggest the digestibility of the diet containing $40 \%$ BSG is not significantly lower than the control and the lower inclusion levels, this could be attributed to fairly low crude fiber level of the BSG and the diets.

The current result showed no significant difference in average body weight changes (BW gains AD gains), and consequently in final body weights as the initial body weights were similar to begin with $(p>0.05)$. This result agrees with (John, 2015) up to $30 \%$ inclusion level. However, (López et al., 1981) alerted on a body weight loss due to $45 \%$ BSG inclusion level. The current result could be justified by the similar dry matter intakes and possible amino acid balance in all the treatments which both determine growth rate of chicken.

\section{Egg production performance, egg weight, egg mass and feed conversion efficiency}

The HDEP and HHEP of each treatment are the same for the absence of any mortality during the experiment. There was very slight and non-significant reduction on hen day egg production as the level of BSG increases along the treatments up to $40 \%$ inclusion level. This result is in disagreement with (Mafeni \& Fombad, 2001) that reported a significant decrease in HDEP at $30 \%$ BSG inclusion level while partially replacing maize and cotton seed cake possibly leading to a higher crude fibre level unlike the current study. However, a $30 \%$ (John 2015) and 40\% (Onwudike, 1981) BSG inclusion level were also tolerated in support of the current result.

The role of NSC in supplementing the amino acid balance of BSG has to be recognized in agreement with (Demeke, 2007) to make the $40 \%$ level tolerable while all the soyabean is taken out from the T5. The essential amino acid such as lysine and methionine content of BSG may need some complementary as confirmed by this study to completely replace soyabean meal, what is regarded as among the best and the most conventional protein source for laying hens.

In this study the comparable CF level of BSG and NSC could have contributed to non-significant difference in feed intake, presumably digestibility and the resulting egg production performance due to the diets at $40 \%$ inclusion level of BSG. The relatively lower level of BSG in four of the diets (T1 up to T4) may have contributed to the lack of adverse effect when it is completely missed from the T5. A reduction in wheat short level progressively from T1 to T5 presumably didn't create significant energy gap confirming the role of BSG as a good source of energy for layers and partly due to the slight increase in Maize grain to maintain iso-calorie between the diets.

The average egg weight of the treatments (1.801.84 ounces) as presented in table 4 are in between medium (1.70 ounces) and large (2 ounces) in reference to USDA classification as cited in (Jacob et al., 2000). The egg weight along the treatments shows a similar trend as the hen day egg production in support of (Fakhraei et al., 2010) but in contrast to (Onwudike, 1981) $(p<0.05)$ and (Mafeni \& Fombad, 2001) that saw a significant progressive increment in egg weight as BSG level increases to $30 \%$. In the current study, the similarity of the diets makes ruling out a different egg protein synthesis pattern among the treatments possible. The slight decline in energy and protein level as the BSG level increases in the treatments seems to negatively correlate with the slight increase in feed intake to compensate for the reducing energy level (McDonald et al., 1995), and to positively correlate with egg weight in agreement with (Mafeni \& Fombad, 2001).

The similar level of CF along the treatments could have made digestibility not to significantly reduce due to higher BSG inclusion levels in contrast to (Mafeni \& Fombad, 2001). The progressive slight non-significant increase in feed intake on one hand and a similar but opposite direction move for egg production has led to a progressively lower, statistically non-significant, feed conversion efficiency as the level of BSG inclusion increases from $0 \%$ to $40 \%$ in agreement with (Onwudike, 1981; Mafeni \& Fombad, 2001; Olajide et al., 2013).

\section{Egg quality}

The variation in external (shell characteristics) and internal (albumin and yolk characteristics) egg quality parameters due the treatments was not significant $(p<0.05)$. Considering the higher BSG 
Gebremedhn B, Niguse M, Hagos B, Tesfamariam T, Kidane T, Berhe A, Gebresilassie L, Gebreegziabher L, Gebremariam T, Gebremeskel Y
Effects of Dietary Brewery Spent Grain Inclusion on Egg Laying Performance and Quality Parameters of Bovans Brown Chickens inclusion levels haven't affected feed intake and egg production significantly may lead to the expectation of no significant difference to egg quality parameters as well. In the report of (Mafeni \& Fombad, 2001), a $30 \%$ BSG inclusion levels significantly reduced hen day egg production while not significantly affecting egg quality parameters. In addition, (Lopez et al., 1981) reported a reduction in egg shell quality at $45 \%$ BSG inclusion level while tolerated the $30 \%$ inclusion level in agreement with (John, 2015) including for other egg quality parameters. All the treatment diets contained beyond the recommended Ca:P ratio (6:1) in (Van Eekeren et al., 2006). The amino acid balance of BSG seems to be commendable as in NSC including its high content of the limiting essential amino acids lysine and methionine (Scott et al., 1982). These seems to be responsible for the lack of significance difference in egg quality and egg production performance as the level of BSG inclusion increased to $40 \%$ as a protein source as supported by (Roberts, 2004). Besides, (Anyanwu et al., 2006) in agreement, reported HU and albumen height are not affected at 37.5\% BSG inclusion level. The HU of the eggs in all treatments of this study are above 72, an AA grade according to USDA (USDA, 2000). The average egg shell thickness and yolk index of the treatments are $\geq 0.32$ and $0.42-0.44$ respectively which are comparable to the results of (Uchegbu et al., $2011 \mathrm{~b})$. The mean yolk color scores of the treatments in this study ranged between 3.7 and 4.4 which are lesser to satisfy much of the consumer preference in many parts of the world (Leeson \& Summers, 1997) including in Ethiopia (Tadelle et al., 2003) where the preference is for deeper yellow yolk color.

\section{Partial economic analysis}

As indicated in Table 6, the highest marginal rate of return is obtained by including higher level of BSG (40\%) and decreased with decreasing level of BSG. Including up to $40 \%$ BSG had better economic advantage without affecting the nutrients supply, laying performance and egg quality.

Regarding profitability analysis, Mafeni \& Fombad (2001) revealed similar results indicating the cost of feed required to produce a $\mathrm{kg}$ of egg output was progressively reduced for $0,10,20$, and $30 \%$ levels of BSG in the ration. Hence, the use of BSG up to $40 \%$ is possible as an alternative to conventional feeds in the diets of egg laying hens to reduce cost of feed specifically and cost of egg production in general.

The study revealed indeed that 40\% BSG inclusion is a tolerable level without causing significant reduc- tion to egg production performance and egg quality parameters of chickens. It can be inferred that higher inclusion level of BSG is tolerable while BSG is replacing a protein source than an energy source like maize as that allows maintaining the crude fiber level of the diets at a tolerable level. A layers' ration can be most profitable with 40\% BSG inclusion level that strengthens the argument for prime relevance of BSG as alternative protein source for chickens.

\section{ACKNOWLEDGEMENTS}

We would like to extend our acknowledgement to Mekelle University for covering costs to undertake this research. The authors are very grateful to Raya Beer share company factory for facilitating the supply of the brewery spent grain.

\section{REFERENCES}

Alemayehu T, Yayneshet T. Comparative Chemical Composition Evaluation of Local Brewery and Liquor By-Products Made from Different Ingredients. Journal of Drylands 2011;4(2):307-309.

Anyanwu G, Uchegbu M, Gwadia W, Mpieri F, Durunna C. Effect of total replacement of maize with brewer's spent grain and maize offal on performance of laying hens. International Journal of Natural and Applied Sciences 2006;2:268-271.

AOAC - Association of Official Analytical Chemists. Official methods of analysis. $13^{\text {th }}$ ed. Washington; 1990 .

Birol E, Asare-Marfo D, Ayele G, Mensa-Bonsu A, Ndirangu L, Okpukpara $B$, et al. Investigating the role of poultry in livelihoods and the impact of avian flu on livelihoods outcomes in africa [discussion paper]. Washington: International Food Policy Research Institute; 2010.

Briggs DE, Brooke SP, Stevens R, Boulton C. Brewing science and practice. Cambridge: Woodhead Publishing Limited; 2004.

CSA - Central Statistical Agency. Report on livestock and livestock characteristics (Private peasant holdings). Addis Ababa: Agricultural Sample Survey; 2017. v.2.

Demeke S. Comparative nutritive value of Atella and industrial brewers grains in chicken starter ration in Ethiopia. Livestock Research for Rural Development 2007;19(1).

Ethiopian-Reporter. Ethiopia: raya to hit bars supermarkets. Washington: All Africa; 2015

Fakhraei J, Loutfollahian H, Shivazad M, Chamani M, Hoseini S. Reevaluation of lysine requirement based on performance responses in broiler breeder hens. African Journal Agricultural Research 2010;5:21372142.

Fărcas A, Tofană M, Socaci S, Mudura E, Scrob S, Salanţă L, et al. Brewers' spent grain - A new potential ingredient for functional foods. Journal of Agroalimentary Processing and Technology 2014;20(2):137-141

Faostat. Food and agriculture organization of the United Nations. Rome: Fao; 2013 [cited 2018 Jan 5]. Available from: http://faostat3.fao.org/ faostat-gateway/go/to/download/Q/QC/S. 
Gebremedhn B, Niguse M, Hagos B,

Tesfamariam T, Kidane T, Berhe A,

Gebresilassie L, Gebreegziabher L,

Gebremariam T, Gebremeskel Y
NRC - National Research Council. Nutrient requirements of poultry: $9^{\text {th }}$ ed Washington: The National Academies Press; 1994

Olajide R, Akinsoyinu AO, lyayi E, Afolabi KD. The effect of brewers dried grains supplemented by enzyme on performance of isa-brown laying hens. PoljoPrivreda 2013;19:65-69.

Onwudike $\mathrm{O}$. The use of brewers dried grains by laying hens. Nutrition Reports International 1981;24(5):1009.

Roberts JR. Factors affecting egg internal quality and egg shell quality in laying hens. The Journal of Poultry Science 2004;41:161-177.

Santos M, Jiménez J, Bartolomé B, Gómez-Cordovés C, Del Nozal M. Variability of brewer's spent grain within a brewery. Food Chemistry 2003;80:17-21

SAS Institute. SAS user's guide: statistics. Version 9.2. Cary: SAS Institute;2008

Scott ML, Nescheim MC, Young RJ. Nutrition of chicken. $3^{\text {rd }}$ ed. New York: M.C. Scott and Associates Ithaca; 1982.

Swain B, Naik P, Chakurkar E, Singh N. Effect of Feeding Brewers' Dried Grain on the Performance of Japanese Quail Layers. Indian Journal of Animal Nutrition 2013;30:210-213.

Tadelle D, Kijora C, Peters K. Indigenous chicken ecotypes in Ethiopia: growth and feed utilization potentials. International Journal of Poultry Science 2003;2:144-152.

Uchegbu MC, Herbert U, Ogbuewu IP, Nwaodu CH, Esonu BO, Udedibie $\mathrm{ABI}$. Performance and egg quality characteristics of layers fed diets containing combinations of brewers dried grains, jack bean and cassava root meal. Revista Científica UDO 156 Agrícola 2011b;11(1):155-160.

Upton M. Farm management in Africa: the principles of production and planning. Cambridge: Cambridge University Press; 1979

USDA - United States Department of Agriculture. Egg-grading manual [Agricultural Marketing Service, 75]. Washington: Departament of Agriculture; 2000. 56p.

Van Eekeren N, Maas A, Saatkamp H, Verschuur M. Small-scale poultry production in the tropics. Wageningen: Agromisa Foundation; 2006.

Wiseman J. Feeding of non-ruminant livestock. London: Butterworth and Co.; 1987.

Zewdu W, Berhan T. The effect of feeding different levels of brewer's dried grain yeast mixture on the performance of white leghorn chicks. International Journal of Livestock Research 2014:5:10-14. 
